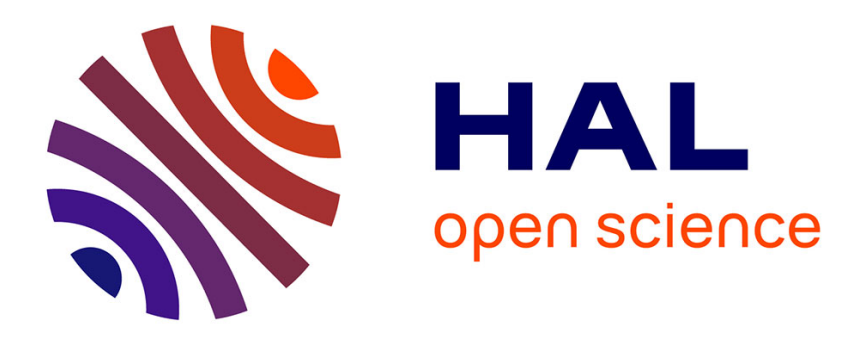

\title{
Indigenous Cosmogony and Andean Architecture in El Alto, Bolivia
}

\author{
Franck Poupeau
}

\section{To cite this version:}

Franck Poupeau. Indigenous Cosmogony and Andean Architecture in El Alto, Bolivia. International Journal of Urban and Regional Research, 2020. hal-03099079

\section{HAL Id: hal-03099079 \\ https://hal.science/hal-03099079}

Submitted on 6 Jan 2021

HAL is a multi-disciplinary open access archive for the deposit and dissemination of scientific research documents, whether they are published or not. The documents may come from teaching and research institutions in France or abroad, or from public or private research centers.
L'archive ouverte pluridisciplinaire HAL, est destinée au dépôt et à la diffusion de documents scientifiques de niveau recherche, publiés ou non, émanant des établissements d'enseignement et de recherche français ou étrangers, des laboratoires publics ou privés. 


$\begin{array}{ll}\text { Publisher } & : \text { John Wiley \& Sons, Ltd } \\ \text { Location } & : \text { Chichester, UK } \\ \text { DOI } & : \text { 10.1111/(ISSN)1468-2427 } \\ \text { ISSN (print) } & : \text { O309-1317 } \\ \text { ISSN (electronic) } & : \text { IJUR-2427 } \\ \text { ID (product) } & : \text { International Journal of Urban and Regional Research } \\ \text { Title (main) } & : \text { Int. J. Urban Reg. Res. } \\ \text { Title (short) } & : \text { 葱 } 2020 \text { Urban Research Publications Limited } \\ \text { Copyright (thirdParty) } & : 9999 \\ \text { Numbering (journalVolume) } & : 9999 \\ \text { Numbering (journalissue) } & : 10.1111 / 1468-2427.12852 \\ \text { DOI } & : \text { IJUR12852 } \\ \text { ID (unit) } & : \text { NA } \\ \text { ID (society) } & : 12 \\ \text { Count (pageTotal) } & : \text { Interventions Essay } \\ \text { Title (articleCategory) } & : \text { Interventions Essay } \\ \text { Title (tocHeading1) } & : \text { 葱 2020 Urban Research Publications Limited } \\ \text { Copyright (thirdParty) } & : 2020-01-25 \text { (SPi Global) } \\ \text { Event (xmlCreated) } & : \text { n/a } \\ \text { Numbering (pageFirst) } & : \text { n/a } \\ \text { Numbering (pageLast) } & : \text { file:ijur12852.pdf } \\ \text { Link (toTypesetVersion) } & : \text { file:ijur12852_am.pdf } \\ \text { Link (toAuthorManuscriptVersion) } & \end{array}$

\title{
INDIGENOUS COSMOGONY AND ANDEAN ARCHITECTURE IN EL ALTO, BOLIVIA
}

\author{
$<<$ Query: Please confirm that given names (blue) and surnames/family names (vermilion) have been \\ identified correctly Ans: Yes>>FRANCK POUPEAU*
}

FRANCK POUPEAU: franck.poupeau@email.arizona.ed

\section{Abstract}

This essay applies Bourdieu's analysis of the formation of the 'scholastic habitus' in medieval times-elaborated in his 1967 afterword to his French translation of Erwin Panofsky's Gothic Architecture and Scholasticism - to the correspondence between indigenous mental categories and architectural innovation the Bolivian 'rebel city' of El Alto. The principle of homology between mental categories and building layout (rooted in a shared habitus) can be used to interpret one of the most spectacular features of Bolivia's 'emerging architectures', known as chalets. The term chalet designates a hybrid structure consisting of a colorful and ornate penthouse and multi-story dwelling erected on building rooftops. The chalets are architectural forms embedded within an economy of symbolic goods characterized by a 'dual truth': they are at once material and symbolic; they perform economic functions while seeking public visibility. The conspicuous lifestyle advertised 
by the construction of chalets can be understood by reference to the rising social power of the indigenous elites (cholos) dominating the thriving 'ethnic economy' of the city. The fraternities of El Alto emerge as the structural equivalent of the scholastic institution that Bourdieu associated with Gothic architecture: they are the site of production of a specific habitus, shared by native urban categories defined by similar residential locations, economic activities and forms of collective organization.

Keywords: architecture; habitus; symbolic power; indigenous bourgeoisie; El Alto; Bolivia; Bourdieu

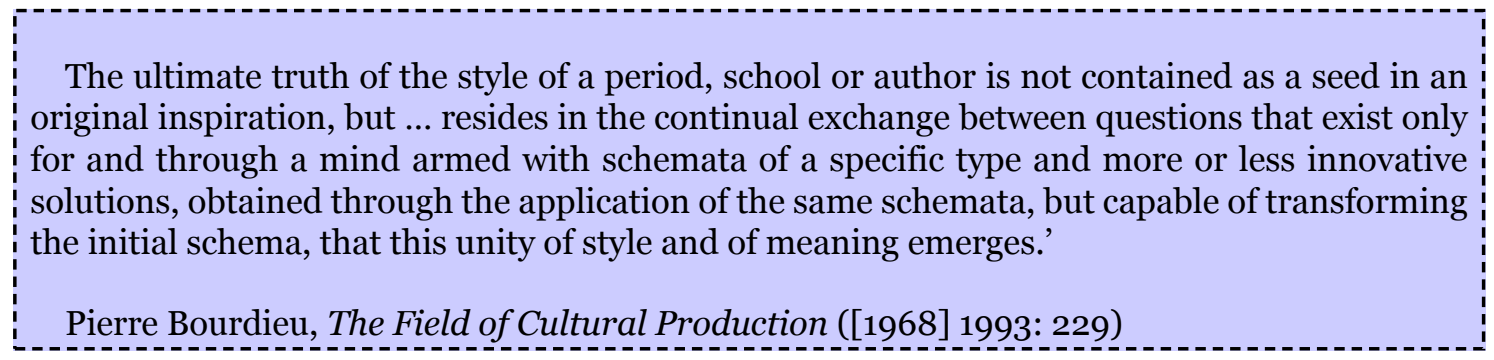

\section{Introduction}

In this essay I apply Bourdieu's analysis of the formation of the 'scholastic habitus' in medieval times, which he elaborated in the afterword to his French translation of Erwin Panofsky's Gothic Architecture and Scholasticism ([1967] 2005), to a different historical case and social context, namely the correspondence between indigenous mental categories and architectural efflorescence in a contemporary city of the Andes. The purpose of Bourdieu's work in this pivotal text-the first in which he theoretically reworks the old philosophical notion of 'habitus'-is to document and explain the homologies obtaining between the structures of the various symbolic systems of a medieval Western Europe, and to uncover the principles of formal conversion that enabling us to navigate from one system to the next. By bringing together two separate texts by Panofsky, the one a social biography of the abbot Suger of Saint-Denis and the other a map of the 'concordances' between the philosophy of the scholastics and the layout of Gothic cathedrals, Bourdieu reveals that a structural correspondence exists between architectural forms and the intellectual patterns generated by the religious institutions entrusted with transmitting culture and knowledge. This approach establishes a 'concrete connection' that accounts for these homologies, namely, the habitus 'through which the creator partakes of his community and time, and that guides and directs, unbeknownst to him, his apparently unique creative acts' (Bourdieu, [1967] 2005: 240). A product of scholastic training, the habitus actualizes 'the very principles that defined the processes of theological thought or the layout of architectural space' to create 'achievements that are both original and reducible to more general schemata' (Bourdieu, [1967] 2005: 236).

This same principle of homology between mental categories and building layout (rooted in a common habitus that will have to be specified) can be used to interpret one of the most spectacular characteristics of 'emerging architectures' in large contemporary cities of the Andes, and in particular the proliferation of eccentric constructions known as chalets in Bolivia. The term chalet, borrowed from the French word for 'log cabin', designates a hybrid structure consisting of a penthouse and multi-story dwelling built on the rooftops of buildings in El Alto, Bolivia, a city situated at the foot of the Royal Cordillera at an altitude of 4,000 to 4,200 meters, on the high plateau (altiplano) overlooking La Paz, the seat of the Bolivian government. These chalets are highly conspicuous owing to their prominent location and sheer size, their angular form, and the garish colors and exuberant decorations using geometric patterns and materials (see Figure 1). Although they look quite different from each other at first sight, they are characterized by 'unity within diversity'. 


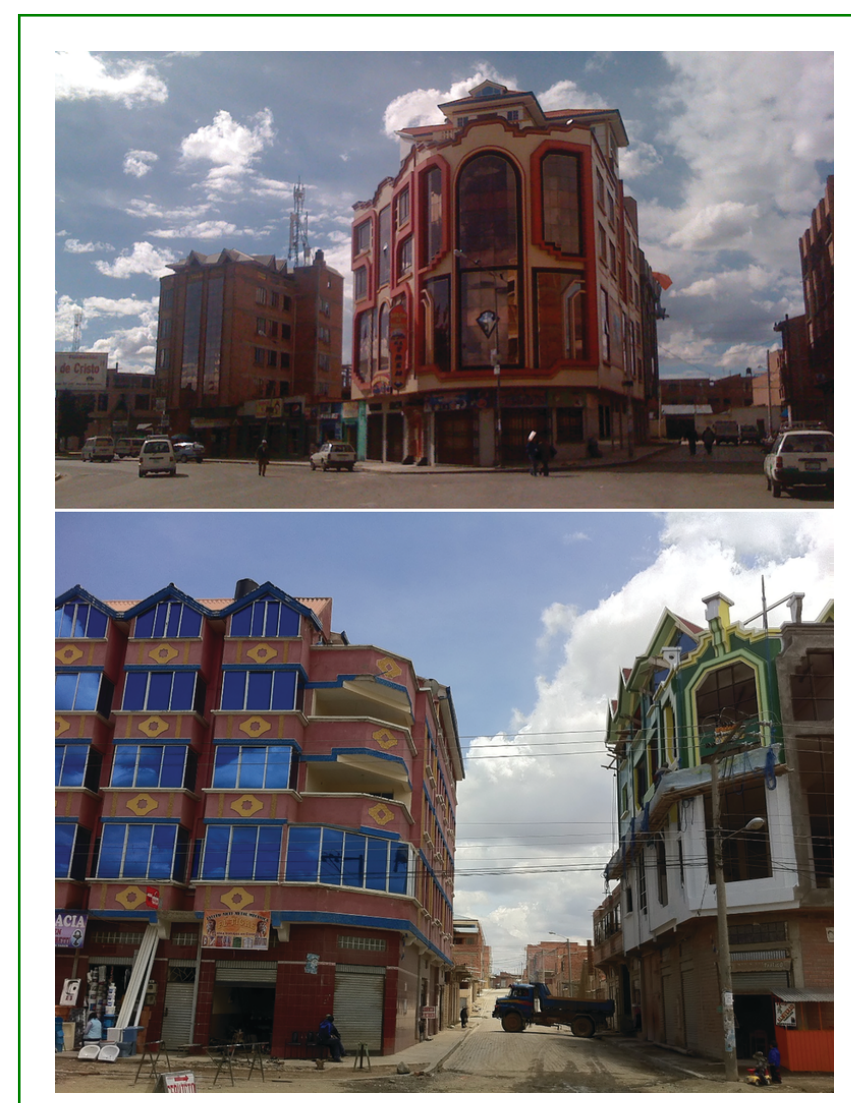

Figure 1 Two chalets in El Alto, with shops and workshops at the lower levels (photos by the author, 2010)

This essay analyzes the chalets as architectural forms embedded within an economy of symbolic goods characterized by a 'dual truth' (Bourdieu, [1997] 2000]): they are at once material and symbolic, performing an economic function while at the same time seeking conspicuous exposure and public visibility. The point here is to not explain this kind of Andean house as a 'cosmos' (Arnold, 1995) by showing how its internal organization reflects a specific vision of natural and social order, based on Bourdieu's early classic study of 'The Kabyle house, or the world reversed' from a structuralist perspective (Bourdieu, [1970] 1990). On the contrary, I emphasize the 'external' or public dimension of this novel architectural design (visibility aspects and aesthetic ornamentations). The chalets represent an obvious demonstration of social and economic power, and their prominent location on the streets and at major crossroads signals the eminence of a specific El Alto social group: a group of successful indigenous entrepreneurs in commerce, transportation or the textile industry-sectors that still account for an important part of the Bolivian economy (35\% in the 200os). The owners of these outlandish houses run family businesses that are deeply enmeshed in the international economy via imports from Brazil, Chile, Peru, the United States or China.

The international nature of these businesses might provide an explanation for the importation of alien architectural forms in an Andean city: a building clearly identified with an architecture coming from Switzerland, one of the wealthiest European countries, can be interpreted as an unvarnished expression of economic success. This ambivalence of the local elites towards a capitalist economy can seem surprising: since the turn of the century, El Alto has been known as the 'rebel city' (Lazar, 2008). The 2003 'gas war' specifically consecrated its population as the avant-garde of Bolivia's political mobilizations in favor of the nationalization of natural resources and a symbol of resistance to neoliberalism. ${ }^{1}$ But how do we understand the production of chalets in this political and territorial context?

I begin by exploring current interpretations of the appropriation of foreign cultural elements-whether these insist on international circulation of architectural forms or on embedding these in a pre-existing local ethnic 
identity. Secondly, I present the urban context of these emergent architectures to characterize the local elites of El Alto. The hypothesis I develop here is that the conspicuous consumption the construction of these chalets on the rooftops of El Alto represent can only be understood with reference to the emerging social power of the indigenous elites (cholos) associated with the local 'ethnic economy'. This essay thus identifies in El Alto the structural equivalent of the scholastic institution that Bourdieu associated with Gothic architecture to illustrate how an architectural form such as the chalet (or, to play on words, the cholets, as they are now often referred to), reveals the formation of a specific habitus, shared among urban groups defined by similar residential locations, economic activities and forms of collective organization.

\section{The internationalization of architectural forms: 'global culture' and 'hegemonic aesthetics'}

Several frames of analysis can be used to understand the specificity of El Alto's chalets. At first sight, it seems plausible to regard the chalets as an import of foreign aesthetics in the context of the globalization of culture and architecture, and as related to the international economy and postcolonial policies. The chalets then express a gradual conversion of the Bolivian urban elites of El Alto to the logics of transnational capital and its symbols of success-after all, the most well-known restaurant in the well-off districts of the city of La Paz is 'La Suisse' ('Switzerland' in French).

Postcolonial studies of the 'built environment' have analyzed the production of space and the way it has been shaped by colonial domination. Researchers have highlighted the contribution of spatial materiality to the formation of social identities (see Blais, 2009), developing the vision of an increasingly architecturally homogenized world', dominated in the twentieth century by the symbolic function of tall buildings. Based on their research, there is a correlation between competitive representations of architectural spectacle and the hierarchies of nation-states. In terms of such a perspective, 'the shaping of the built environment is a writing of the history of a nation' (Kusno, 2000)-a history that can be dominating or dominated, depending on the country. Consequently, the emergent Bolivian architectural forms studied here would not have originated in the indigenous cities but from outside the country, as part of a broader 'global architecture'.

According to Anthony King, 'a particular type of individual and consumer-oriented form of outer suburbanization, as well as occasional leisure space, represented by a distinctive (though varying) form of one storey dwelling (everywhere referred to by the same term-'bungalow'), has developed in "advanced" and especially post-industrial societies' (King, 2004: xiii). He regards the bungalow as 'the one perfect house for all tropical countries' (ibid.: 51). This tropical urbanism marks out new regional or national identities that can be imported across the transnational spaces of the 'metropole' and the 'postcolony' as tropical architecture. Kusno uses the same postcolonial perspective when he mentions that 'to achieve this translocal regionalist architecture, the preceding forms of dominance represented by modernist architecture will thus have to be rearticulated ... In a self-inscribed alterity to the modernist-international architecture, the category of "tropical" climate becomes a symbol for a locally-meaningful architecture ... This represents a process of architectural "localization," a cultural negotiation of the authority of the international style' (Kusno, 2000: 200).

While these postcolonial studies insist on the role of the built environment in the reproduction of domination, they have more difficulties bringing out the specificity of indigenous cultures. Indigenous cultural practices are regarded as hybridized products of global and local elements, but conflicts for power inside the 'native' communities remain relatively unexplored. Even Brenda Yeoh's research on conflicts in urban organization in Singapore reveal that the urban built environment (the physical structures-such as houses, roads, factories, offices, sewerage systems, parks, cultural institutions, educational facilities) 'ideally reflected the power and prestige of the colonialists' and that the 'colonial landscape ... is structured to enhance the flow of economic activities such as trade and communications which were crucial to the entire colonial economy' (Yeoh, [1996] 2003: 16). Finally, postcolonial studies rely on the hypothesis that 'symbolic capital is not so much created as moved around from one temporary landmark to another' (Dovey, 1999: 121) without real appropriation by local subaltern groups. 
To understand the logics of importation without reducing it to the 'global' dissemination of the same forms (Bishop et al., 2003), I take into account local structures of reception of such symbolic goods (Bourdieu, 1999: 220-28). A comparative and historical point of view can be useful here. In La Casaque d'Arlequin (1997), historian Heliana Salguerio studies the importation of baroque ornamental mantling on the edges of roofs in Belo Horizonte, Brazil, at the end of the nineteenth century. Criticized for their lack of fit to the country, these forms, named chalets too, represented variations of a style imported from Switzerland, adjusted to rich households and mixed with references to English cottages. The Brazilian version of the chalet embodied an eclectic juxtaposition that assimilated industrial and technical innovations as decorative elements, especially wood or metal mantling, and stuccoed elements on gable walls with a Renaissance floral design (Daly, 1872). El Alto's chalets, by contrast, are not merely an ornamental importation, as they have an economic function and are produced by an economic elite that is both locally implanted and internationally connected. From this perspective, it may not have been coincidence that the textile craft entrepreneurs of El Alto developed strong relations with Brazil since the 1990s, owing to the increased migration of Bolivian workers to São Paulo (Vidal, 2012).

As an indirect effect of migration, chalets may reveal the dynamics of indigenous cultures and their capacity to appropriate foreign elements to integrate them with elements of local identities. How should we understand such processes of importation? For Randolph Cárdenas (2010), 'emergent architectures' in urban Bolivia are an expression of the cultural innovation of the Aymara population. Transpositions to urban contexts of principles rooted in rural constructions and corresponding to the collective organization of rural communities (Abercrombie, 1998) are the main characteristic of these architectural forms. But Cárdenas does not elaborate on how we should understand the emergence of these innovative symbolic forms that are being implemented in the urban contexts of El Alto but refer back to the rural world.

Reinhard Bentmann and Michael Müller strove to explain such a relation in their study of the emergence of the Italian villa as a dream of the countryside in the sixteenth century in the context of Venetian economic growth (Bentmann and Müller, 1992). The Renaissance villa appears to be an ideological transfiguration whereby a group of landholders from the urban bourgeoisie claimed control of newly constituted latifundia (large landed estates) in the countryside. Thus, the emergence of the villa is seen not only in relation to the economic logic of incipient Venetian capitalism but also in the context of the larger 'city versus campus' conflict. The villa expressed the claims of an ascendant class, to counter the general logic of Western postfeudal society towards ever greater urban concentration: for example, the landscape was used as a decoration for the villa and to assert claims for domination analogous to those of the ancient nobility. It was necessary to use the forms of the classical art of antiquity as appropriate forms for this new dominant elite, and to realize a kind of 'secularized paradise on earth' reserved for the select few: 'architecture stood as the intersection of the cosmological, the astrological and the social perspectives' (ibid.: 53). If the villa reproduced the architectural structures of domination of the Venetian Renaissance city, this actualization of past aesthetical forms referred also to the 'dream of the countryside' as a timeless ideology and a conservative posture. ${ }^{2}$

This vision of the villa as 'hegemonic architecture' helps us understand, from the Gramscian perspective of the authors, the relationships, both coercive and ideological, that constitute aesthetics as an indicator of transformation of social power. This architecture was about 'the self-assurance of those who could still use pinnacles and towers as symbols of their social or political demands' (ibid.: 106). Bentmann and Müller hypothesize that the penthouses and the villas are 'hostile to urbanization', as they express a 'dream of urban flight' and a 'desire for undisguised status symbols': 'the penthouse is situated high above the netherworld of common existence and on top of the flat roof of the tower block. As such, it satisfies the demands both for a luogo privilegiado and for a sito elevato, which were postulated by Renaissance theoreticians with regard to the villa as hegemonic architecture ... Besides the function of surveying and overseeing, which the penthouse shares with the villa owing to a sito elevato, there is also the idea in common of a prospect, or belvedere ... In its contemporary form, the penthouse too is antiurban, as long as it remains a privileged site for a few wealthy individuals' (ibid.: 135, 136).

However, in the case of chalets in El Alto, the emergence of a new elite (the cholo entrepreneurs) does not reveal the same kind of 'dream of the countryside' as that of families belonging to the rural communities of the altiplano. On the contrary, these new elites used a Western architectural form (the chalet) to show their 
new economic power: this architectural form, built atop building, expresses their aspirations, but indicates their wish to remain rooted in urban relationships and economics-and not the city. Finally, the Gramscian analytical frame of Bentmann and Müller keeps the material and symbolic aspects of architectural practices separate: in fact, these practices represent the economic determination of a new elite that elaborates an (antiurban) ideology and builds a new kind of architecture to express its domination. To avoid the reduction of such social forms of existence to bare economics, we have to look more closely at the social logics of the local economy to understand the 'dual truth' of what could be regarded as an 'anti-economic economy' (Bourdieu, [1997] 2000: 192).

\section{The familial and informal economy of El Alto}

The cities of El Alto and La Paz are generally studied on the basis of the opposites of center versus periphery, rich versus poor, and so on. The two conurbations are characterized by deep inequalities in terms of infrastructure. The development thereof may be attributed to the differences between their respective economic potentials and histories. El Alto is situated on the altiplano above the Bolivian capital city of La Paz (at around 4,000 meters above sea level), while the rich live in the lower parts of the metropolis (wealthy neighborhoods lie at 3,200 to 3,500 meters above sea level). Since it was founded, El Alto has provided housing for and become home to subaltern groups working in the capital city, and as an outlying settlement it has always had the economic function of providing additional labor and available space. Over the course of the twentieth century, owing to a lack of space in La Paz, economic activities that were formerly carried out there (such as transport, arts and crafts, retail, manufacturing) moved to El Alto. The lower classes, including low-paid public-sector workers and the underemployed, have been inexorably pushed outwards, especially to the high plateau overlooking the city. There they were joined by growing cohorts of rural migrants looking for work when they could no longer subsist on the small and drought-ridden plots of land they inherited following the Agrarian Reform of 1954. Consequently, El Alto experienced exponential population growth. It increased from 11,000 inhabitants in 1950 to 300,000 inhabitants in the early 1970 , to 640,000 in 2001 , and to around one million in 2010. Today, El Alto is characterized by unique and sharply defined sociospatial inequalities (Poupeau, 2009): its inner ring, made up of the oldest and most compact neighborhoods, includes administrative buildings and small artisanal and commercial enterprises that were developed in the 1940s; a second ring is devoted to economic activities; while a third ring, less densely urbanized and more extensive, is the product of the endogenous growth of the metropolis and of the tendency of lower-income middle-class working families to purchase land in less expensive areas on which they can build their own houses (Poupeau, 2010).

In the 2000s, the El Alto workforce comprised $47 \%$ manual workers and clerical or commercial employees and $40 \%$ independent workers. ${ }^{3}$ Wholesale and retail business represented $30 \%$ of economic activities, while industry and crafts weighed in at $23 \%$, transport at $10 \%$ and construction at $8 \%$. These figures suggest that El Alto is not a homogeneously poor city, but encompasses a vast range of economic activities: it hosts more than 5,000 firms, of which $90.6 \%$ are small family businesses that employ between one and four workers and account for $45 \%$ the of working population of El Alto (CDILP, 2004). More than a thousand new businesses are created each year in the textile, transportation, food production and arts and crafts sectors. However, 70\% of the working population is active in the informal sector (in which young, female and indigenous people are overrepresented).

The economy of El Alto can thus be characterized as a familial and informal economy. However, during the national census of 2001, the city's population declared itself to be mostly indigenous. ${ }^{4}$ Therefore it can also be regarded as an ethnic economy. This notion, developed by Olivia Harris (2000), originally refers to the organized production and circulation of goods that can be accomplished on a large scale outside the formal market, based on self-organization of the ethnic group. It forms the basis of rural indigenous economies and can be extended to urban areas that remain characterized by rural social relations. The term cholos refers to urbanized indigenous highlanders from the Aymara communities who have come to live in La Paz and El Alto since colonization (Socuro Sologuren, 2011) but do not subscribe to the 'denial of one's identity, one's past, 
one's origin' (Harris, 1995: 365) that characterizes the urban mestizo populations who ascended to the spheres of power from the nineteenth century.

Cholos are generally known to reject locally dominant bourgeois values, such as unpretentiousness and thriftiness. They 'run a thriving transnational economy of conspicuous consumption placing moral emphasis on spending in excess, and rapidly materializing profit into abundant display-whether through dress, through exhibition of goods or through religious parades. Despite their economic affluence, cholos remain a rather discriminated group from the rest of the urban mestizo population for their supposed failure to submit to laws of economic rationality' (Tassi, 2010: 193). Their economic and religious practices are driven by a principle of abundance as a salient economic and cosmological value associated with the reproduction of goods and cosmological relations. They provide insight into a form of market economy in which excess, rather than scarcity, operates as the motivating force for exchange' (ibid.: 195). From this perspective, they belong to a kind of 'anti-economic economy' (Bourdieu, [1997] 2000: 192), if economy is conceived of as the dominant form of rational calculation characteristic of capitalism.

Symbolically, the chalets seem to signify such a denial of the economy-they are ostentatious, excessively costly and functionally unnecessary-but at the same time, they represent common knowledge of the economic dimension of the entire construction (in the logic of family businesses). They are intended to be seen by the neighbors (vecinos) but also to showcase individual success. As an architect in El Alto writes, 'Lo que la gente quiere es: "como de mi vecino, pero major"' (What people want is: 'like my neighbor, only better') (quoted in Cárdenas, 2010: 25). However, to reduce the construction of the chalets to a mere imitation of neighbors' houses ignores the embeddedness of these building in complex social relations. They are typically added to buildings that consist of units with multiple economic functions: there might be a shop or a workshop on the ground floor, a reception room, large and colored window panes on the first floor that opens on to the second floor, an apartment or offices for rent on the third floor, and family housing on the fourth level and in the 'chalet', a term that implies different uses of the top floor from the uses that are typical of rural communities (see Figure 2).

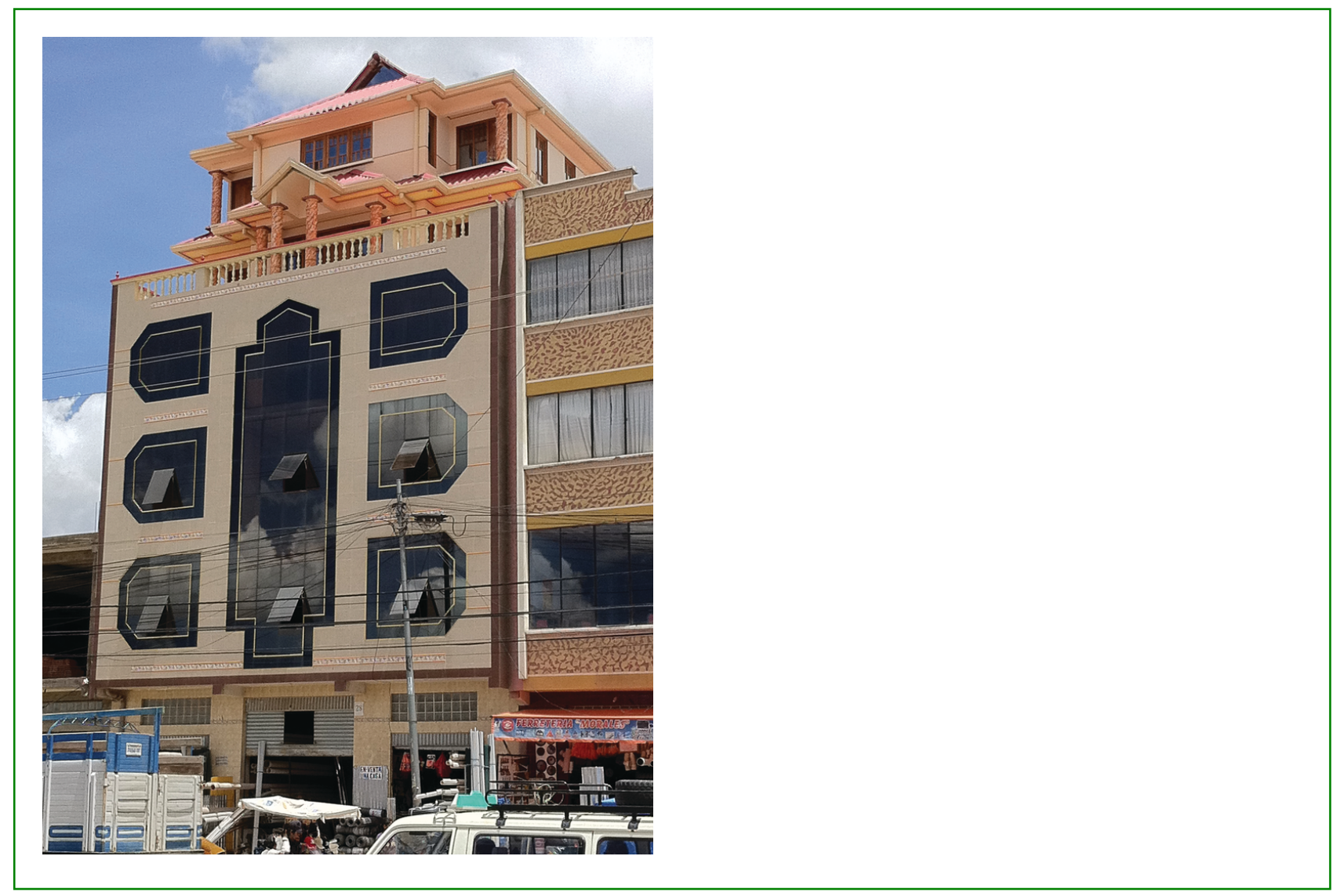


Figure 2 A typical chalet above the busy Avenue 16 de Julio of El Alto, with a shop (tienda) on the first floor, and the large window of a two-level reception room above it (photo by the author, 2010)

To understand the dual truth of the social logics expressed in these emergent architectures and their denial of a rational economy, an explanation of how those schemata are generated is necessary, on the basis of Panofsky's method developed by Bourdieu in his 'Postface to "Gothic Architecture and Scholasticism" ([1967] 2005).

\section{Looking for homologies: cholo architecture and Andean fraternities}

Bourdieu revives Panofsky's iconological approach to study the homologies between the structures of the various symbolic systems of a society, and to show the principles of formal conversion between them. A 'concrete connection' accounting for these homologies is provided by the habitus produced by the insertion of the creator into the socializing group (Bourdieu, [1967] 2005: 240). This habitus actualizes and embodies the general schemata that shapes theological thought as well as architectural forms (ibid.: 236). Even if it is not possible, in this first outline, to be so precise as, for example, Panofsky's analysis of the 'homology between the ribs [croisées d'ogive] and the break of Gothic writing' (Bourdieu, [1967] 2005), it is still possible to identify a few aesthetic characteristics-such as mixed colors, materials, hierarchy of forms-that reveal a 'unity of style' and the implementation of the same schemata through various social practices. To transfer Bourdieu's analysis from medieval Europe to the twenty-first-century Bolivian context, we must, however, fulfil two conditions.

First, we must show that the construction of the chalets arises from the logic of the social practices of the cholo elites. Interviews with architects working in El Alto confirm the decisive role of the homeowners in shaping and designing each building: ${ }^{5}$ architects as members of a profession distinct from the local elites play only a technical and juridical role, by helping to ensure that the construction is complies with local municipal guidelines. A form of professional contempt has arisen among architects working in El Alto: they mock the buildings and complain that the owners of the chalets do not know the basic rules of architectural coherence. This lack of harmony is considered less an expression of singular taste than a lack of architectural competence on the part of people who are not professionals and employ maestros albañiles (bricklayers) to construct these buildings. 'If one uses cornices, balusters, columns, lintels and arcades on the windows ... for architects it's a postmodernist style badly applied' (Cárdenas, 2010: 63). Therefore, the chalets cannot be considered the product of institutionalized and professional craftsmanship, but part of the lifestyles of the local elites that fund them.

Secondly, to transpose Bourdieu's analysis to the Bolivian case, it is necessary to identify the institution that could produce the homologies between the aesthetic schemata invested in the construction of the chalets as a specific architectural form. No equivalent to the scholastic seminary can be found in the Bolivian school system, since most cholo elites received little formal schooling-especially since the transmission of culture and knowledge is not monopolized by schools in Bolivian society (Widmarck, 2003). To understand the homology, we need to identify the local institution that molds the principles of perception, appreciation and action that organizes the meaning of the cholo group in public spaces. The hypothesis presented here is that the only collective form of organization that possesses such capacity in El Alto is constituted by the fraternities based on professional corporations (as associations of individual entrepreneurs). A historical and comparative perspective supports this hypothesis.

In another context, Max Weber ([1921] 1982) showed that urban fraternities as organizations based on an economic activity are characterized by how they occupy public space: they have residential, confessional and cultural dimensions, as revealed by a comparison of Protestant sects and medieval corporations. Medieval corporations were not more coercive than sects, but they did not tolerate individual commitment to economic success, as sects did, because such success would undermine the principles of corporate bonds (Weber, [1906] 2000: 341-42). Consequently, individual success had to be denied in its economic dimension to allow for the meshing of individual and collective logics. The principle of abundance in cholo fraternities is very similar 
to this ambivalent attitude towards economy, and it is conceivable that the prominence of Catholicism with its powerful colonial legacy in the Andean highlands prevents a massive conversion of the cholo elites to Protestant asceticism-or even to the Pentecostal versions that have found widespread support in South America in recent decades (Orta, 2004) and that characterizes, according to Weber, the 'spirit of capitalism'.

To return to the use of public space in El Alto, the most visible expression of corporations among local elites are parades and carnivals (see Figure 3) that take place regularly on the streets of the city (Harris, 1995; Guss, 2008; Hempele, 2008). Each group that participates in a parade is financed by a pasante (sponsor), who belongs to a fraternity whose colors feature in the participants' costumes (Albó and Preiswerk, 1991). Chalets constitute another manifestation of this affirmation of collective corporate identity in the city. Through the buildings and their material and symbolic-or economic and aesthetic-dimensions, the elites of the ethnic economy located in El Alto compete for the use of public space with local economic rivals. They compete in the streets by funding the most magnificent parade and producing the most visible-and original-chalet.

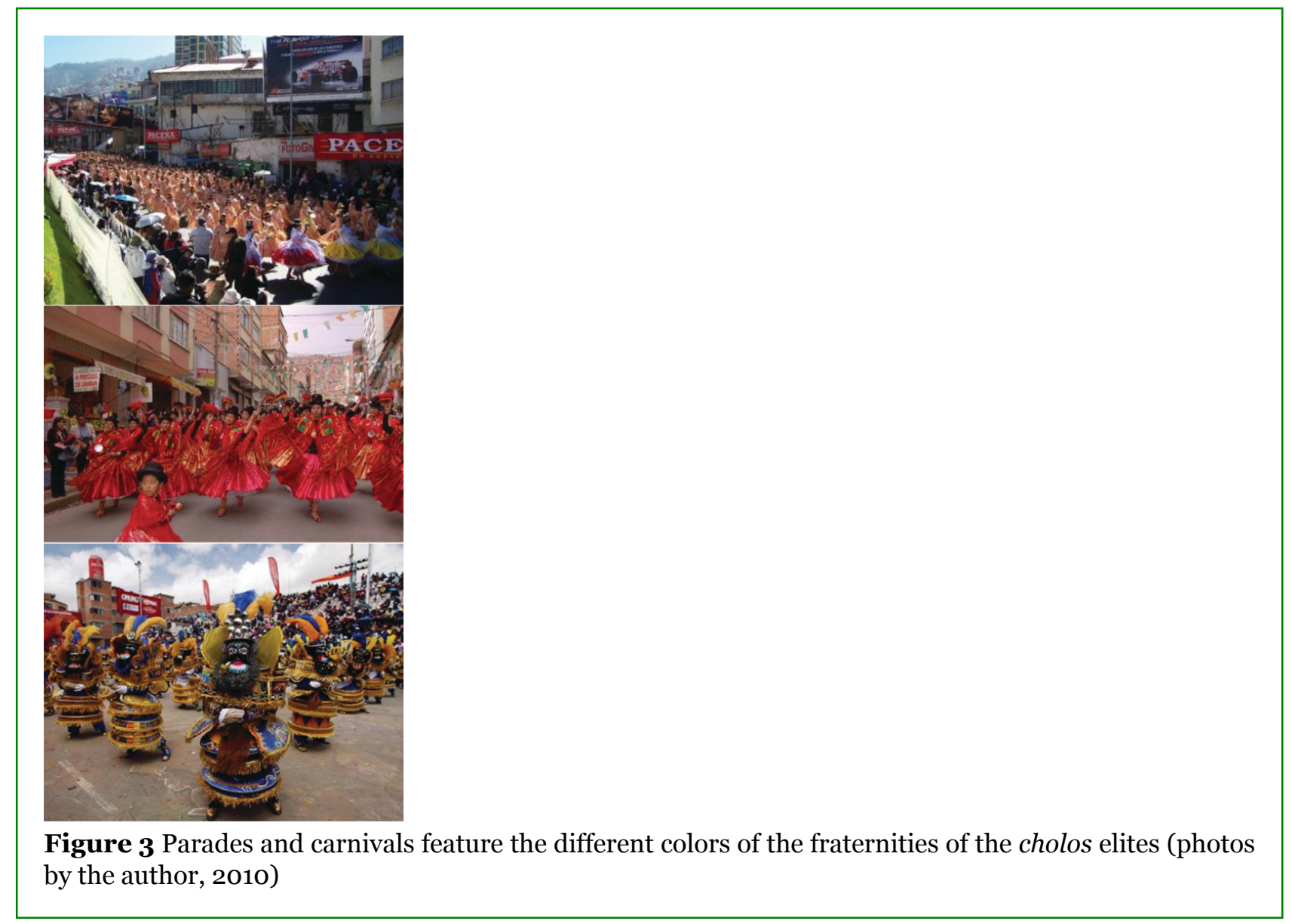

Thus, we may hypothesize that economic corporations as fraternities in El Alto are the distinctive social matrix that shapes a habitus that denies economic interest and is evident from the cholo elites' attitude towards conspicuous manifestations of success and social power. The chalet thus is not a materialized mythic Andean cosmology characterized by a logic of gift and counter-gift presumed to exist beyond market exchange (Larsson and Harris, 1995) but rather signifies an ambivalent attitude towards the capitalist economy: an accumulation of economic capital oriented towards a conspicuous demonstration of symbolic power. Consequently, these architectural forms are not only part of the material built environment: they are symbolic forms that reveal the dual truth of the social logics that generate them and are situated 'at the heart of the transmutation that is the basis of symbolic power, a power that is created, accumulated and perpetuated through ... symbolic exchange' (Bourdieu, [1997] 2000: 199). 
Finally, this <<Query: Please add page number of proof to citation in 12849 Ans: I don't find it >>analysis of the chalets shows that the appropriation of foreign Western 'elements' enters into the production of original symbolic forms that cannot be reduced either to the international circulation of global architecture nor to the urban persistence of an ethnic identity generated in rural communities. The homologies between symbolic forms (chalets) and social structures (fraternities) allow us to uncover the generative principles of architectural aesthetics, and to take into account the dual truth of these constructions, in terms of their material and symbolic aspects. The transposition of Bourdieu's analysis of the homologies between scholastic doctrines and Gothic architecture in medieval Europe to recent architectural innovation among the indigenous commercial elites of urban Bolivia thus reveals a specific habitus towards the economy. The hypothesis is that the principles of this habitus are produced by and productive of a private sphere exposed to public view in a conspicuous way, which 'transfigures economic capital into symbolic capital' (Bourdieu, [1997] 2000: 199). In the context of El Alto, the familial economy embeds the capitalist market and sustains the elites' aspiration of being part-a dominant part-of urban and capitalist life. The denial of an economy operated, among other dimensions of the cholo elites' lifestyles, by the emergent architectures can provide a key to how these elites can simultaneously accumulate profits in an informal and unequal capitalist economy, while also claiming an indigenous identity that has been shaped by recent mobilizations against neoliberalism.

\section{References}

Abercrombie, T.A. (1998) Pathways of memory and poder: ethnography and history of an Andean comm unity. University of Wisconsin Press, Madison, WI.

Albó, X. and M. Preiswerk (1991) El Gran Poder: fiesta del Aimara urbano [The Gran Poder: festival of the urban Aymara]. América Indígena 51.2/3, 293-352.

Arnold, D. (1992) La casa de adobes y piedras del Inka: genero, memoria y cosmos en Qaqachaka [The ado be and stone houses of the Inca: gender, memory and cosmos in Qaqachaka]. In D. Arnold (ed.), Hacia un orden Andino de las cosas: tres pistas de los Andes meridionales [Towards an Andean order of things: thr ee tracks in the southern Andes], Hisbol/Ilca, La Paz.

Bentmann, R. and M. Müller ([1970] 1992) The villa as hegemonic architecture. Humanities Press, Londo n.

Bishop, R., J. Phillips and W. Yeo (2003) Perpetuating cities: exception globalization and the Southeast Asia supplement. In R. Bishop, J. Phillips and W. Yeo (eds.), Postcolonial urbanism: Southeast Asian citie $s$ and global processes, Routledge, New York and London.

Blais, H. (2009) Coloniser l'espace: territoires, identités, spatialité [Colonizing space: territories, identitie s, spatiality]. Genèses 74, 145-59.

Bourdieu, P. ([1967] 2005) Postface to 'Gothic architecture and scholasticism', translated by L. Wacquant. I $\mathrm{n} \mathrm{B}$. Holsinger, The premodern condition: medievalism and the making of theory, University of Chicago $\mathrm{P}$ ress, Chicago, IL.

Bourdieu, P. ([1968] 1993) Outline of a sociological theory of art perception. In P. Bourdieu, The field of cu ltural production: essays on art and literature, Columbia University Press, New York. 
Bourdieu, P. ([1970] 1990) The Kabyle house or the world reversed. In P. Bourdieu, The logic of practice, P olity, Cambridge.

Bourdieu, P. ([1997] 2000) The twofold truth of the gift. In P. Bourdieu, Pascalian meditations, Polity, Ca mbridge.

Bourdieu, P. (1999) The social conditions of the international circulation of ideas. In R. Schusterman (ed.), Bourdieu: a critical reader, Blackwell, New York.

Cárdenas, R. (2010) Arquitecturas emergentes en El Alto: el fenómeno estético como integración cultural [Emerging architectures in El Alto: the aesthetic phenomenon as cultural integration]. PIEB, La Paz.

CDILP (Cámara Departamental de Industrias de La Paz) (2004) Encuesta de necesidades de desarollo emp resarial en la industria manufacturera en la ciudad El Alto [Survey of business development needs in the manufacturing industry in the city of El Alto]. CDILP, La Paz.

Daly, C. (1872) L'architecture privée au XIX ${ }^{\circ}$ siècle, volume 2: villas, chalets, jardins et leurs dépendances [Private architecture in the nineteenth century, volume 2: villas, chalets, gardens and their various outbui ldings]. Ducher \& Cie, Paris.

Dovey, K. (1999) Framing places: mediating power in built form. Routledge, London and New York.

Guss, D. (2008) The Gran Poder and the reconquest of La Paz. Journal of Latin American Anthropology 11.2, 294-328.

Harris, O. (1995) Ethnic identity and market relations: Indians and mestizos in the Andes. In B. Larson an d O. Harris (ed.), Ethnicity, markets and migration in the Andes: at the crossroads of history and anthrop ology, Duke University Press, Durham, NC, and London.

Harris, O. (2000) To make the earth bear fruit: ethnographic essays on fertility, work and gender in high land Bolivia. School of Latin American Studies, London.

Hempele, J. (2008) Arenas of circulation and ethnographic circuits. In J. Hempele, Circuits of culture: me dia, politics and indigenous identity in the Andes, University of Minnesota Press, Minneapolis, MN.

King, A. (2004) Spaces of global cultures: architecture, urbanism, identity. Routledge, London and New Y ork.

Kusno, A. (2000) Behind the postcolonial: architecture, urban space and political culture in Indonesia. $\mathrm{R}$ outledge, London and New York. 
Larsson, B. and O. Harris (eds.) (1995) Ethnicity, markets and migration in the Andes. Duke University $\operatorname{Pr}$ ess, Durham, NC, and London.

Lazar, S. (2008) El Alto, rebel city: self and citizenship in Andean Bolivia. Duke University Press, Durham, NC.

Orta, A. (2004) Catechizing culture: missionaries, Aymara, and the 'new evangelization'. Columbia Unive rsity Press, New York.

Poupeau, F. (2009) El Alto, una ficción política [El Alto, a political fiction]. Bulletin de l'Institut Français d'études Andines 39.2, 542-65.

Poupeau, F (2010) De la migración rural à la movilidad intra-urbana: una perspectiva sociológica sobre las desigualdades de acceso al agua en El Alto (Bolivia) [From rural migration to intra-urban mobility: a sociolo gical perspective on inequalities of access to water in El Alto (Bolivia)]. In F. Poupeau and C. Gonzalez And ricain (eds.), Modelos de gestión del agua en los Andes [Water management models in the Andes], IFEA/P IEB, Lima.

Salgueiro, H. (1997) La casaque d'arlequin: Belo Horizonte, une capitale éclectique au XIX $X^{e}$ siècle [The ha rlequin's jacket: Belo Horizonte, an eclectic capital in the nineteenth century], Ecole des Hautes Etudes en Sciences Sociales, Paris.

Socuro Sologuren, X. (2012) La ciudad de los cholos: mestizaje y colonialidad en Bolivia siglos XIX y XX [The city of the cholos: the mestizos and coloniality in Bolivia in the nineteenth and twentieth centuries]. I FEA/PIEB, Lima and La Paz.

Tassi, N. (2010) The postulate of abundance: cholo market and religion in La Paz, Bolivia. Social Anthropo logy/Anthropologie Sociale 18.2, 191-209.

Vidal, D. (2012) Vivre et travailler entre différents cadres juridiques: les migrants Boliviens dans le secteur de la confection à São Paulo [Living and working between different legal frameworks: Bolivian migrants in $\mathrm{t}$ he clothing sector in São Paulo]. Revue Européenne des Migrations Internationales 28.4, 109-26.

Weber, M. ([1906] 2000) Les sectes Protestantes et l'esprit du capitalisme [The Protestant sects and the spi rit of capitalism]. In M. Weber, L'éthique Protestante et l'esprit du capitalisme [The Protestant ethic and $t$ he spirit of capitalism], Flammarion, Paris.

Weber, M. ([1921] 1982) La ville [The city]. Aubier, Paris.

Widmarck, C. (2003) To make do in the city: social identities and cultural transformations among Aymar a speakers in La Paz. Uppsala Studies in Cultural Anthropology 36, Acta Universitatis Upsaliensis, Uppsal a. 
Yeoh, B. ([1996] 2003) Contesting space: power relations and the urban built environment in colonial Sin gapore. Oxford University Press, Oxford.

${ }^{1}$ This cycle of protests translated to a $53.7 \%$ share of the first round vote for Evo Morales in the presidential el ections of 2005. Morales' platform reflected, on the one hand, a desire to help indigenous people who had bee $\mathrm{n}$ the victims of 500?years of colonial and later postcolonial rule and, on the other hand, the wish to reclaim $\mathrm{p}$ ublic ownership of the country's natural resources.

${ }^{2}$ Bentmann and Müller ([1972] 1992) show how, for example, in eighteenth- and nineteenth-century England, during the initial phase of industrialization, factory owners transferred their place of residence to the immedia te proximity of the production plants. Thereby they actualized the form of the villa to express their new econo mic and social power.

${ }^{3}$ The National Institute of Statistics (INE) classifies as 'independent workers' people who do not belong to a p ublic administration or a private company, but are the owners of their own business.

${ }^{4}$ More than $80 \%$ of people in El Alto declared to belong to a 'native nation' (such as Aymara, Quechua or Guar ani)-more than the average percentage in the Bolivian population (61\%).

${ }^{5}$ Interviews presented in this essay were conducted by the author in June 2010 and December 2011 with 11 arc hitects from La Paz and El Alto, as part of a project on 'Ciudades Andino-Amazónicas, Ciudades Globales', spo nsored by the IFEA (Institut Français d'études Andines) and the PIEB (Programa de Investigaciones Estratégi cas en Bolivia). This preliminary project is now part of a larger project funded by the ANR and UMI iGLOBES (CNRS/University of Arizona) since 2012 on 'Social Conflicts and the Paradoxes of Conservative Politics in the Americas', within the framework of the BlueGrass program.

\section{Author Biography}

Franck Poupeau, UMI <<Query: Please check email address. Should it be @email.arizona.edu? Ans: Replace UMI... with : CNRS, IFEA La Paz (Bolivia) / CREDA Campus Condorcet Bâtiment de recherche sud 5, cours des Humanités, 93322, Aubervilliers

franck.poupeau@cnrs.fr>>3157 CNRS/University of Arizona, Harshbarger Building, 1133 East James E. Rogers Way, Tucson, Arizona 85721, USA, franck.poupeau@email.arizona.ed 